\title{
PEMBERDAYAAN MASYARAKAT DALAM PENGEMBANGAN DESA WISATA URONGO KECAMATAN TONDANO SELATAN KABUPATEN MINAHASA PROVINSI SULAWESI UTARA
}

Oleh

\author{
Suraji $^{1}$, Ruli Sumual ${ }^{2}$, Piet Pusung ${ }^{3}$, Ferdinadus Jaftoran ${ }^{4}$, \\ Nadia E Sasanaung ${ }^{5}$, Vivi Maisyaroh ${ }^{6}$, Ni Luh Putu Dewi ${ }^{7}$ \\ 1, 2, 3, 4) Institut Pememrintahan Dalam Negeri Kampus Sulawesi Utara \\ suraji1772@gmail.com
}

5, 6,7) Muda Wanita Praja (MWP) Institut Pememrintahan Dalam Negeri Kampus Sulawesi Utara

\begin{abstract}
$T_{d}$ his research was conducted to know about community empowerment efforts in the development of Urongo Tourism Village as well as to know various supporting factors and inhibitory factors in these empowerment activities. This type of research is descriptive qualitative. Informants in this study include the Head of The Cultural and Tourism Office of Minahasa Regency, officials of the Head of Tourism, Culture, Arts and Promotion at the Department of Culture and Tourism of Minahasa Regency, Lurah Urongo Village, Tourists in Urongo Tourism Village, and Urongo community residents. Data collection techniques are through interviews, observations, and documentation. The technique of checking the validity of data using source triangulate. Data analysis techniques use the steps put forward by Miles and Huberman, namely data collection, data reduction, data presentation, and conclusion drawing.

The results showed that in community empowerment activities in the development of Urongo Tourism Village there are supporting factors and inhibitory factors. Optimal community empowerment efforts, namely partnerships and mentoring assistance. Efforts that have not been optimal are not yet receiving assistance from PNPM Mandiri Tourism, limited development of facilities and infrastructure, and the absence of Pokdarwis and Tourism Village Managers. While in the development of Urongo tourism village the optimal aspects are partnership, promotion, development of social institutions, and cooperation with universities and that have not been optimal is the development of human resources, development of facilities and infrastructure, government activities, lack of events/competitions and the establishment of Pokdarwis and Tourism Village Managers. The supporting factors are tourism potential and good community response and have received PNPM assistance. While the inhibitory factor is the quality of human resources, the lack of legal basis that governs tourist villages, Pokdarwis and tourism village managers, the lack of optimal government activities, and the weak recording of tourism data.
\end{abstract}

Keywords: empowerment, community development, tourism village

\section{Abstrak}

Denelitian ini dilakukan dengan tujuan untuk mengetahui tentang upaya-upaya pemberdayaan masyarakat dalam pengembangan Desa Wisata Urongo serta mengetahui berbagai faktor 
pendukung dan faktor penghambat dalam kegiatan-kegiatan pemberdayaan tersebut. Jenis penelitian ini adalah deskriptif kualitatif. Informan pada penelitian ini antara lain Kepala Dinas Budaya dan Pariwisata Kabupaten Minahasa, para pejabat Kepala Bidang Pariwisata, Budaya, Kesenian dan Promosi pada Dinas Budaya dan Pariwisata Kabupaten Minahasa, Lurah Kelurahan Urongo, Pelaku Wisata di Desa Wisata Urongo dan warga masyarakat Urongo. Teknik pengumpulan data yaitu melalui wawancara, observasi dan dokumentasi. Teknik pemeriksaan keabsahan data menggunakan triangulasi sumber. Teknik analisis data menggunakan langkahlangkah yang dikemukakan oleh Miles dan Huberman, yaitu pengumpulan data, reduksi data, penyajian data dan penarikan simpulan.

Hasil penelitian menunjukkan bahwa dalam kegiatan pemberdayaan masyarakat dalam pengembangan Desa Wisata Urongo terdapat adanya faktor pendukung dan faktor penghambat. Upaya pemberdayaan masyarakat yang cukup optimal yaitu kemitraan dan bantuan pendampingan. Upaya yang belum optimal yaitu belum menerima bantuan PNPM Mandiri Pariwisata, terbatasnya pembangunan sarana dan prasarana dan belum adanya Pokdarwis dan Pengelola Desa Wisata. Sedangkan dalam pengembangan Desa Wisata Urongo aspek yang cukup optimal yaitu kemitraan, promosi, pembinaan lembaga sosial dan kerja sama dengan perguruan tinggi dan yang belum optimal adalah pengembangan SDM, pengembangan sarana dan prasarana, kegiatan pemerintahan, kurangnya even/lomba dan belum terbentuknya Pokdarwis dan Pengelola Desa Wisata. Adapun faktor pendukung yaitu potensi wisata dan adanya respons masyarakat yang baik dan pernah mendapat bantuan PNPM. Sedangkan faktor penghambat yaitu kualitas SDM, belum adanya dasar hukum yang mengatur desa wisata, Pokdarwis dan pengelola desa wisata, kurang optimalnya kegiatan pemerintahan dan lemahnya pencatatan data kepariwisataan.

Kata kunci: pemberdayaan, pengembangan masyarakat, desa wisata

\section{PENDAHULUAN}

P rospek industri pariwisata di Indonesia sangat luar biasa karena potensi wisata yang dimilikinya sangat luar biasa. Dengan potensi wisata yang dimiliki maka sektor pariwisata menjadi salah satu sektor yang memberi kontribusi kepada Produk Domestik Bruto Indonesia. Yang menarik dan mencengangkan ternyata kontribusi sektor pariwisata terhadap Produk Domestik Bruto relatif besar. Pertumbuhan PDB dari sektor pariwisata mengalami peningkatan yang cukup signifikan setiap tahunnya. Di samping itu sektor pariwisata juga merupakan salah satu sektor yang banyak menyerap tenaga kerja, mampu mendongkrak produk-produk domestik ke pasar internasional dan tentunya dapat meningkatkan taraf hidup masyarakat.
Sektor pariwisata itu sendiri merupakan sektor yang bersifat multisektoral dan multidimensi. Berbagai pihak yang memiliki kepentingan dalam sektor pariwisata yaitu pemerintah baik pemerintah pusat maupun pemerintah daerah, pihak swasta di antaranya yaitu biro travel, maskapai, hotel dan operator tour kemudian wisatawan yaitu wisatawan mancanegara dan wisatawan Nusantara. Pihak lain yang juga memiliki kepentingan yaitu penduduk lokal, kelompok/lembaga masyarakat nirlaba seperti LSM-LSM, peneliti, perguruan tinggi dan pihak lain penunjang pariwisata.

Pengembangan pariwisata juga dilaksanakan oleh Pemerintah Sulawesi Utara. Dengan potensi yang dimiliki dalam wilayahnya Pemerintah Provinsi Sulawesi Utara menjadikan sektor pariwisata sebagai salah satu andalan. Dengan melaksanakan berbagai program dan terobosan dilakukan dan yang paling fenomena yaitu pembukaan jalur penerbangan langsung dari Manado ke 
beberapa kota di China seperti Shanghai dan Guangzhou. Hal ini berhasil meningkatkan jumlah kunjungan wisatawan ke Sulawesi Utara. Selanjutnya pengembangan pariwisata juga dilakukan oleh pemerintah daerahpemerintah daerah di Provinsi Sulawesi Utara salah satunya yaitu Kabupaten Minahasa yang memiliki potensi sumber daya alam, seni budaya dan pariwisata.

Potensi wisata yang dimiliki oleh Kabupaten Minahasa cukup lengkap dalam arti hampir semua jenis destinasi wisata ada. Menurut data Dinas Pariwisata dan Budaya Kabupaten Minahasa memiliki 141 tempat wisata. Yang paling dikenal adalah Danau Tondano sebagai ikon Kabupaten Minahasa. Kemudian destinasi wisata lain yaitu air terjun Tahapan Telu dan Tincep, Pemandian air panas Karumega, Arum Jeram Timbukar, Desa kerajinan keramik Pulutan,Lembah pinus Toliang Oki, Situs sejarah Watu Pinabentengan, Pantai Mangatasik Tombariri, Pantai Kombi, Pantai Kora-kora dan Pantai Kolongan. Juga terdapat beberapa situs bersejarah seperti Goa Jepang, Loji Tondano, Benteng Moraya dan Dermaga Tasuka yang digunakan pada saat perang dunia II, gereja tertua yaitu Gereja GMIM Watumeadi. Potensi wisata yang ada didukung dengan berbagai sarana dan prasarana penunjang di antaranya 32 hotel dan penginapan dengan rincian 1 Hotel Bintang 4, 1 hotel bintang 3 , kemudian 2 hotel bintang 2, dan 28 hotel nonbintang (melati dan penginapan) dengan jumlah kamar mencapai 539. Kemudian restoran dan rumah makan yaitu 78 yang tersebar di berbagai wilayah. Biro travel yang mendukung kegiatan wisata sejumlah 10, diving centre ada 12 buah dan ada 38 sarana camping ground,ruang konser dan teater. Dengan berbagai upaya yang dilakukan guna mengembangkan pariwisata di Kabupaten Minahasa dan didukung berbagai sarana dan prasarana pendukung dan penunjang lainnya memperoleh hasil yang cukup baik yaitu adanya peningkatan kunjungan wisatawan di Kabupaten Minahasa setiap tahunnya baik wisatawan domestik maupun wisatawan mancanegara.

Seiring dengan upaya pengembangan pariwisata maka patut dicermati adalah adanya perubahan fenomena tentang ketertarikan para wisatawan dengan destinasi wisata yang memiliki nuansa yang berbeda, kemudian muncul dan berkembang konsep pariwisata yang disebut dengan desa wisata. Desa wisata bermacam-macam jenisnya yaitu ada yang berbasis seni budaya, nuansa alam, adanya tradisi atau ritual dan dapat pula berbasis kesenian atau kerajinan. Di Kabupaten Minahasa telah memulai pengembangan sebagai desa wisata di antaranya yaitu Desa Rumbia, Desa Pulutan, Desa Kanonang dan selanjutnya disusul Desa Tandengan, Urongo dan Peleloan. Untuk desa wisata yang berkembang cukup pesat yaitu desa Rumbia, Desa Pulutan dan Desa Kanonang.

Salah satu desa wisata yang mempunyai potensi sangat baik tetapi belum menunjukkan perkembangan yaitu Desa Wisata Urongo. Permasalahan yang ada di antaranya sarana dan prasarana belum tersedia secara optimal. Kemudian akses jalan yang rusak dan lebar jalan masih relatif sempit. tidak memiliki lahan parkir Kondisi-kondisi tersebut di atas salah satunya disebabkan karena pemberdayaan masyarakat dalam pengembangan Desa Wisata Urongo masih belum optimal.Belum optimalnya pengembangan wisata di Urongo salah satunya disebabkan masyarakat Urongo belum menyadari akan pentingnya pariwisata sehingga mereka kurang ikut serta dalam pengembangan desa wisata.

Penelitian tentang pemberdayaan masyarakat dalam pengembangan Desa Wisata Urongo Kecamatan Tondano Selatan Kabupaten Minahasa ini bertujuan untuk mengetahui upaya-upaya yang dilakukan untuk memberdayakan masyarakat dalam pengembangan Desa Wisata Urongo dan faktor pendukung dan faktor penghambatnya 


\section{METODE PENELITIAN}

Penelitian ini menggunakan penelitian deskriptif dengan pendekatan kualitatif, atau bisa disebut penelitian deskriptif kualitatif. Dalam penelitian ini sumber data penelitian yaitu pihak-pihak yang dapat memberikan informasi dan data yang dibutuhkan dalam penelitian yaitu Kepala Dinas pada Dinas Pariwisata dan Budaya Kabupaten Minahasa, para Kepala Bidang di Dinas Pariwisata dan Budaya Kabupaten Minahasa (Kepala Bidang Pariwisata, Kepala Bidang Promosi, Kepala Bidang Budaya, Kepala Bidang Kesenian), Lurah Urongo, Sekretaris Lurah/Perangkat Desa terkait Kelurahan Urongo, kelompok sadar wisata dan pengelola desa wisata, penjaga karcis, pemilik home stay, pemilik usaha warung dan warga masyarakat.

Teknik pengumpulan data yang digunakan penelitian adalah wawancara, observasi, dan dokumentasi.Dalam proses penelitian, peneliti menggunakan pedoman observasi dan pedoman wawancara. Teknik pemeriksaan keabsahan data dalam penelitian ini menggunakan teknik triangulasi.

Teknik triangulasi yang digunakan oleh peneliti dalam penelitian ini adalah triangulasi sumber. Teknik analisis data yang digunakan dalam penelitian ini menggunakan langkah-langkah seperti yang dikemukakan oleh Miles dan Huberman yaitu pengumpulan data, reduksi data, penyajian data dan penarikan simpulan.

\section{HASIL PENELITIAN}

\section{Pemberdayaan Masyarakat dalam Pengembangan Desa Wisata Urongo}

Dalam pemberdayaan masyarakat dalam pengembangan Desa Wisata Urongo telah dilakukan dengan beberapa tahapan Tahapan pertama adalah tahap penyadaran dan pembentukan perilakumenuju perilaku sadar dan peduli sehingga merasa membutuhkan peningkatan kapasitas diri. Masyarakat pada tahap ini mulai muncul kesadaran akan pentingnya pemberdayaan masyarakat dalam pengembangan Desa Wisata Urongo. Munculnya kesadaran pentingnya pariwisata ini salah satunya dipicu oleh keberhasilan Provinsi Sulawesi Utara yang dinilai berhasil dalam pengembangan pariwisatanya dan menjadi salah satu destinasi wisata yang diunggulkan dan meningkatnya jumlah wisatawan Nusantara dan wisatawan mancanegara ke Provinsi Sulawesi Utara. Juga adanya trend desa wisata dalam kepariwisataan nasional yang ditandai dengan pemberitaan kesuksesan berbagai desa wisata yang mampu meningkatkan kesejahteraan masyarakatnya walaupun potensi yang dimiliki biasa saja. Masyarakat Desa Wisata Urongo menyadari hal ini dan memiliki keyakinan jika masyarakat dapat berpartisipasi maka dapat berperan serta dalam mengembangkan Desa Wisata Urongo.

Tahapan kedua yaitu tahap transformasi kemampuan berupa wawasan pengetahuan, kecakapan, keterampilan agar terbuka wawasan dan memberikan keterampilan dasar sehingga dapat mengambil peran di dalam pembangunan. Pada tahap ini Dinas Budaya dan Pariwisata Kabupaten Minahasa memberikan sosialisasi dan pelatihan-pelatihan kepada pemerintah desa dan kelurahan yang ditetapkan sebagai desa wisata, pokdarwis dan pengelola desa wisata yang ada di Kabupaten Minahasa termasuk Desa Wisata Urongo. Sasarannya yaitu bagi pemerintahan desa dan kelurahan dapat merencanakan program yang mampu mendukung pengembangan desa wisata termasuk pemberdayaan masyarakatnya. Sasaran bagi pihak yang langsung terkait yaitu pokdarwis dan pengelola yaitu agar anggota pokdarwis dan pengelola desa wisata mendapat kesempatan memperoleh pelatihan-pelatihan sebagai kader pelopor pengembangan desa wisata. Selanjutnya para kader yang telah mengikuti pelatihan menjadi kader dapat memberikan pelatihan kepada masyarakat. Penyelenggaraan 
kegiatan pelatihan dilakukan oleh Dinas Budaya dan Pariwisata Kabupaten Minahasa dan juga Dinas Budaya dan Pariwisata aktif berkoordinasi dengan Dinas Pariwisata Provinsi Sulawesi Utara jika ada program pelatihan.

Tahapan ketiga yaitu tahap peningkatan kemampuan intelektual, kecakapanketerampilan sehingga terbentuklah inisiatif dan kemampuan inovatif untuk mengantarkan pada kemandirian. Pada tahap ini masyarakat sudah mendapatkan pelatihan dalam kegiatan pemberdayaan. Pelatihan ini bertujuan untuk dapat mengembangkan potensi-potensi yang dimiliki untuk dapat dikembangkan dengan modal inisiatif dan kemampuan inovatif.

Kemudian Mengenai pemberdayaan masyarakat dalam pengembangan Desa Wisata Urongo ditinjau dari aspek-aspek pemberdayaan yakni: (a) Bantuan modal. Kelurahan Urongo telah menerima bantuan PNPM dari tahun 2012, 2013,2015 dan 2016 serta Bantuan Program Kotaku tahun 2017. Bantuan PNPM dan Bantuan Program Kotaku tersebut yaitu dalam rangka meningkatkan kualitas lingkungan hidup dan kesehatan masyarakat. (b) Bantuan pembangunan prasarana. Bantuan pembangunan prasarana di Desa Wisata Urongo yaitu sasarannya adalah pembangunan sarana untuk pengembangan lokasi wisata Tree House yang merupakan ikon Desa Wisata Urongo. (c) Bantuan pendampingan. Tenaga pendamping dari Dinas Budaya dan Pariwisata Kabupaten Minahasa yaitu Enggel Anggoman dan Jonathan Montolalu. (d) Penguatan kelembagaan. Saat ini Pokdarwis di Desa Wisata Urongo belum ada. Dengan belum adanya Pokdarwis di Desa Wisata Urongo maka pengembangan Desa Wisata Urongo belum dapat berjalan dengan optimal. (e) Penguatan Kemitraan Pemberdayaan masyarakat di Desa Wisata Urongo dilakukan oleh berbagai aktor yang terlibat. Konteks kemitraan dalam pemberdayaan masyarakat dalam pengembangan Desa Wisata Urongo adalah kemitraan yang terjalin antara aparat pemerintahan Kelurahan Urongo, Dinas Budaya dan Pariwisata Kabupaten Minahasa, perguruan tinggi-perguruan tinggi di wilayah Sulawesi Utara dan instansi-instansi pemerintah lain seperti Kementerian KKP, BP DAS Tondano, PLN, TNI dan Polri.

\section{Bentuk Pengembangan Desa Wisata Urongo}

Bentuk pengembangan Desa Wisata Urongo meliputi: (a) Pengembangan SDM. Pengembangan sumber daya manusia di Desa Wisata Urongo dilakukan melalui pelatihan-pelatihan, diskusi, maupun kegiatan lain yang berhubungan dengan kepariwisataan. (b) Kemitraan. Kemitraan yang telah dilaksanakan yaitu dengan perguruan tinggi-perguruan tinggi yang ada di Sulawesi Utara. Kemitraan dengan Universitas Negeri Manado yaitu sebagai lokasi Kuliah Kerja Nyata atau KKN Mahasiswa. Kemitraan dengan Universitas Sam Ratulangi dalam hal kegiatan penelitianpenelitian. Kemitraan dengan STIPAR Manado dan Politeknik Manado jurusan pariwisata. (c) Kegiatan pemerintahan. Kegiatan pemerintahan di desa yang dapat dilakukan antara lain seperti pelaksanaan musyawarah perencanaan pembangunan/ musrenbang tingkat kelurahan, sosialisasi rapat-rapat dinas, keikutsertaan dalam pameran pembangunan dan lain-lain, (d). Promosi Promosi yang dilakukan Desa Wisata Urongo adalah dengan mengikuti berbagai pameran, peliputan oleh media televisi, iklan, promosi penjualan, pemasaran dari mulut ke mulut,dan publikasi. Pameran yang rutin diselenggarakan adalah pameran pembangunan Kabupaten Minahasa pada peringatan proklamasi kemerdekaan dan hari jadi Kabupaten Minahasa. Peliputan oleh media televisi yang difasilitasi oleh Dinas Budaya dan Pariwisata Kabupaten Minahasa.

Promosi dapat dilakukan oleh berbagai pihak dan yang utama adalah 
warga masyarakat dengan memanfaatkan aktivitas di media sosial. (e) Lomba-lomba. Pengembangan Desa Wisata Urongo melalui kegiatan lomba yang pernah dilakukan yaitu lomba foto pemandangan danau Tondano yang cukup sukses meningkatkan popularitas Urongo sebagai desa wisata. (f) Membina organisasi masyarakat. Organisasi atau lembaga masyarakat yang memiliki potensi dalam pengembangan Desa Wisata Urongo di antaranya adalah PKK, Dasa Wisma, Generasi Muda Pencinta Alam dan komunitas pelaku seni,(g) Kerja sama dengan universitas. Kerja sama yaitu dalam bidang pendidikan melalui kegiatan pengembangan akademik dan kegiatan pengabdian.

\section{Faktor Pendukung dan Penghambat Pemberdayaan Masyarakat dalam Pengembangan Desa Wisata Urongo}

\section{a. Faktor pendukung.}

Dalam kegiatan pemberdayaan masyarakat dalam pengembangan Desa Wisata Urongo di lapangan terdapat faktor pendukung dan penghambat. Faktor pendukung dalam penelitian ini yaitu, pertama, potensi wisata yang ada di Desa Wisata urongo dapat dikembangkan menjadi potensi pariwisata yang dapat memajukan perekonomian desa. Kedua, semangat dan respons positif dari masyarakat. Keterlibatan masyarakat sebagai pelaku wisata sudah ditunjukkan oleh masyarakat dalam kegiatan penjagaan loket, pemandu wisata, penjual makanan dan lain sebagainya. Ketiga, bantuan PNPM. Pemerintah Kelurahan Urongo telah pernah memperoleh bantuan PNPM sebanyak empat kali, yaitu pada 2012, 2013, 2015 dan 2016, serta Bantuan Program Kotaku pada 2017.

\section{b. Faktor penghambat.}

Faktor penghambat yang ditemukan dalam penelitian ini adalah kualitas SDM masyarakat Desa Wisata Urongo.
Tingkat pemahaman masyarakat dalam hal kepariwisataan dapat dikatakan masih rendah. Kedua yaitu belum adanya peraturan atau dasar hukum. Selanjutnya pelestarian budaya Minahasa dan ciri khas kehidupan manusia danau relatif kurang dan mulai hilangnya ciri khas kehidupan manusia danau. Faktor lain yaitu kegiatan pemerintahan di Desa Wisata Urongo yang belum optimal serta kurangnya data-data terutama terkait pencatatan kunjungan wisatawan.

\section{PEMBAHASAN HASIL PENELITIAN}

Dalam pemberdayaan masyarakat dalam pengembangan Desa Wisata Urongo telah dilakukan dengan beberapa tahapan yang harus dilalui seperti yang dikemukakan oleh Ambar Teguh Sulistiyani (2004: 83) sebagai berikut. Tahapan pertama adalah tahap penyadaran dan pembentukan perilaku menuju perilaku sadar dan peduli sehingga merasa membutuhkan peningkatan kapasitas diri. Masyarakat Desa Wisata Urongo menyadari pentingnya pariwisata dan memiliki keyakinan jika masyarakat dapat berpartisipasi dalam mengembangkan Desa Wisata Urongo.

Tahapan kedua yaitu tahap transformasi kemampuan berupa wawasan pengetahuan, kecakapan, keterampilan agar terbuka wawasan dan memberikan keterampilan dadar sehingga dapat mengambil peran di dalam pembangunan. Pihak-pihak yang langsung terkait yaitu pokdarwis dan pengelola desa wisata mendapat kesempatan memperoleh pelatihan-pelatihan sebagai kader pelopor pengembangan desa wisata.

Tahapan ketiga yaitu tahap peningkatan kemampuan intelektual, kecakapanketerampilan sehingga terbentuklah inisiatif dan kemampuan inovatif untuk mengantarkan pada kemandirian. Pada tahap ini masyarakat sudah mendapatkan pelatihan dalam kegiatan pemberdayaan. Potensi-potensi yang dimiliki dapat 
dikembangkan dengan modal inisiatif dan kemampuan inovatif di antaranya potensi keindahan alam, hasil danau dan hasil pertanian, kuliner kemudian potensi terkait seni kerajinan yang dapat menghasilkan souvenir yang layak

Pemberdayaan masyarakat dalam pengembangan Desa Wisata Urongo ditinjau dari Bantuan modal. Dalam sebuah kegiatan pemberdayaan masyarakat, aspek permodalan merupakan salah satu komponen yang penting. Selain itu, masalah permodalan menjadi salah satu aspek yang sering dihadapi seperti tidak adanya modal yang cukup walaupun memiliki potensi yang besar. Ketiadaan atau kekurangan modal dapat mengakibatkan tidak dapat memulai suatu usaha atau melakukan usaha tetapi minimal sehingga perkembangannya lambat. Kelurahan Urongo telah menerima berbagai bantuan dan telah dimanfaatkan namun secara nyata hasil dari pemanfaatan bantuan PNPM dan Program kotaku tersebut mendatangkan manfaat bagi masyarakat secara umum, tetapi tidak sepenuhnya mengena langsung terhadap pengembangan desa wisata. Hal ini dapat dimaklumi karena memang telah ssuai pemanfaatannya dengan sasaran yang telah ditetapkan dalam program.

Dalam rangka pengembangan desa wisata maka bantuan yang dibutuhkan memang berupa bantuan modal yang terkait langsung atau besentuhan langsung dan digunakan untuk modal mengembangkan desa wisata. Adapun untuk bantuan modal yang dimaksud adalah dalam bentuk PNPM Mandiri Pariwisata. PNPM Mandiri Wisata dalam pemberiannya disesuaikan dengan rancangan pengembangan desa wisata setiap tahunnya dan memiliki tahapan pengembangan yang jelas arah dan sasarannya. Pada awal pembentukan, bantuan yang didapat dari PNPM Mandiri Pariwisata tersebut dapat digunakan untuk penguatan kelembagaan dan kapasitas SDM. Dari adanya bantuan tersebut kemudian dapat dibentuk kelompok sadar wisata (pokdarwis) dan pengelola desa wisata. Pokdarwis dan pengelola desa wisata yang dibentuk harus memenuhi kriteria/ persyaratan terutama wawasan dan kemampuan manajerial misalnya memiliki konsep rencana pengembangan desa wisata yang jelas. Kejelasan yang ada sangat penting sehingga pengembangan desa wisata tidak hanya hanya sekadar formalitas saja tetapi dapat dipertanggungjawabkan dan dapat dioperasionalkan. Dengan demikian maka bantuan modal yang diterima dapat dikelola dengan baik.

Dengan adanya bantuan modal PNPM Mandiri Pariwisata tersebut Pokdarwis dan pengelola Desa Wisata Urongo harus dapat mengelola keuangan secara efektif dan efisien. Salah satu yang kegiatan pengelolaan keuangan tersebut yaitu melakukan pengeluaran sebagai modal awal. Perlu adanya perencanaan penggunaan modal awal yang jelas sehingga dalam melakukan pengeluaran misalnya membeli barangbarang maka dari barang-barang yang dibeli tersebut akan menghasilkan output yang dapat dijual sehingga menghasilkan keuntungan yang lebih besar lagi. Contoh penggunaan modal awal yaitu untuk penyusunan rancangan pengembangan desa wisata, kegiatan bedah potensi dan pengembangannya, pembelian perlengkapan seperti perlengkapan perkemahan (camping) untuk penggunaan wisata alam bagi penggemar kegiatan perkemahan dan sebagainya. Dengan demikian, modal yang cukup sangat menentukan untuk dilaksanakannya kegiatan organisasi dan keberhasilan usaha pengembangan Desa Wisata Urongo.

Pemberdayaan masyarakat dalam pengembangan desa wisata pada aspek bantuan prasarana merupakan usaha untuk mendorong masyarakat agar berdaya. Tersedianya prasarana di tengah-tengah masyarakat yang kurang berdaya akan mendorong dan meningkatkan mereka untuk 
menggali potensi-potensi yang dimilikinya. Selain itu, dengan adanya prasarana akan memudahkan mereka untuk melakukan aktivitasnya. Berdasarkan data penelitian menunjukkan kurangnya prasarana yang ada. Oleh karenanya dibutuhkan suatu konsep pengembangan yang berbasis masyarakat.Dalam pengembangan desa wisata dikenal istilah pengembangan dengan konsep community based tourism yaitu konsep pengembangan wisata di mana masyarakat turut andil dalam perencanaan, pengembangan, serta pengelolaannya. Untuk dapat menerapkan konsep ini maka pemerintah Kelurahan Urongo, Dinas Budaya dan Pariwisata Kabupaten Minahasa dan masyarakat Urongo harus sepakat bahwa pengelolaan Desa Wisata Urongo dilaksanakan oleh, dari dan untuk masyarakat. Keberadaan destinasi wisata Tree House yang telah ada sebelumnya dan telah menjadi ikon yang telah dikenal oleh masyarakat luas harus dapat disinergikan atau dikolaborasikan dengan pengembangan Desa Wisata Urongo dengan tetap saling menguntungkan.

Oleh karena infrastruktur merupakan pendukung utama dalam kehidupan seharihari masyarakat, terlebih untuk kegiatan kepariwisataan di Desa Wisata Urongo, alangkah baiknya apabila pembangunan fasilitas infrastruktur tersebut dibangun sesuai dengan konsep pengembangan desa wisata sesuai basic-nya. Sebagai desa wisata yang mengandalkan aspek keindahan alam dan aktivitas masyarakat yang masih alami dan berciri seni, budaya/tradisi maka pembangunan prasarana harus dapat menunjangnya. Infrastruktur dirancang dan dibangun akan membuat wisatawan merasa nyaman ketika berkunjung ke Desa Wisata Urongo. Semakin baik kualitas infrastrukturnya maka akan meningkatkan jumlah kunjungan wisatawan dan semakin besar pula tingkat perekonomian desa wisata tersebut. Adapun prasarana tersebut misalnya gardu pandang, taman buatan, sanggar seni dan monumen ucapan selamat datang/meninggalkan desa wisata. Prasarana Gardu pandang dapat digunakan untuk menunjang aktivitas pengunjung dalam menikmati dan mengeksploitasi keindahan alam. Taman-taman buatan dengan berbagai jenis tanaman yang indah selain menambah keindahan juga potensi sebagai spot bermain dan berfoto yang berkesan. Sanggar seni yang lengkap dengan sarana perlengkapan/ peralatan dapat dijadikan pusat latihan dan juga tempat ajang menampilkan seni dan budaya tradisional. Monumen selamat datang/memasuki/meninggalkan desa wisata urongo dapat didesain yang menarik. Kemudian juga pembangunan prasarana bagi destinasi wisata yang sudah siap yaitu Tree House agar lebih menarik dan mampu sebagai ikon Urongo seperti gerbang area masuk lokasi, tempat parkir, toilet dan warung, tangga jalan menuju bagian atas lokasi yang masih sederhana.

Sedangkan dalam hal bantuan pendampingan pada dasarnya merupakan upaya untuk menyertakan masyarakat dalam mengembangkan berbagai potensi sehingga mampu mencapai kualitas kehidupan yang lebih baik. Selain itu pendamping dapat memfasilitasi proses pengambilan keputusan yang terkait dengan kebutuhan masyarakat, membangun kemampuan dalam meningkatkan pendapatan,melaksanakan usaha yang berskala bisnis serta mengembangkan perencanaan dan pelaksanaan kegiatan partisipatif. Yang menjadi perhatian adalah mengenai siapa yang paling efektif menjadi pendamping masyarakat karena pemberdayaan masyarakat merupakan proses yang berkelanjutan.

Edi Suharto (2005: 93) menguraikan bahwa pendampingan merupakan salah satu strategi yang sangat menentukan keberhasilan program pemberdayaan. Selanjutnya Primahendra (2002: 6) mengatakan bahwa pendampingan adalah kegiatan pemberdayaan masyarakat dengan 
menempatkan tenaga pendamping yang berperan sebagai fasilitator, komunikator, dan dinamisator.

Berkaitan dengan itu, peran pendamping di Desa Wisata Urongo harus dapat berperan sebagai motivator, yaitu berupaya untuk menyadarkan dan mendorong masyarakat untuk mengenali potensi dan masalah yang ada. Dari mengembangkan potensi tersebut kemudian akan memecahkan permasalahan yang ada. Selanjutnya pada tahap pelaksanaan, peran pendamping berusaha memberikan pengarahan dan pelatihan pemandu wisata, manajemen wisata, pembukuan tentang wisata, struktur organisasi, pengelolaan objek wisata, bahasa asing, kuliner, dan manajemen pengelolaan wisata perdesaan. Pada tahap ini, pendamping mempunyai tanggung jawab untuk menciptakan, mengondisikan iklim kelompok yang harmonis, serta memfasilitasi terjadinya proses saling kerja sama dalam kelompok.

Dinas Budaya dan Pariwisata Kabupaten Minahasa dalam hal pendampingan ini menyiapkan tenaga pendampingan yaitu dari kalangan mahasiswa, tenaga ahli dan juga memanfaatkan Sumber daya Manusia yang ada di Dinas Budaya dan Pariwisata Kabupaten Minahasa yang memiliki latar belakang pariwisata. Adapun tugasnya yaitu memantau hasil-hasil pelatihan yang telah diikuti oleh peserta pelatihan sebagai kader. Tenaga pendamping juga wajib turun langsung memonitor ke lapangan dan setiap minggu melaporkan hasil tugasnya. Tenaga pendamping juga memiliki target untuk mengader tenaga pendamping lokal yaitu warga masyarakat setempat.

Pada aspek penguatan kelembagaan. Maka terkait dengan lembaga yang berhubungan langsung dengan pengelolaan Desa Wisata Urongo yaitu pokdarwis dan kesekretariatan pengelola desa wisata, Pemerintah Kelurahan dan Dinas Budaya dan Pariwisata Minahasa. Dengan belum adanya Pokdarwis di Desa Wisata Urongo maka pengembangan Desa Wisata Urongo belum dapat berjalan dengan optimal. Oleh karenanya pembentukan Pokdarwis harus menjadi prioritas untuk segera dilakukan pembentukan. Dalam pembentukannya agar lembaga tersebut dapat menjalankan tugas dan fungsinya dengan baik perlu dipilih dan ditetapkan. Dalam hal ini peran Lurah Orongo dan Dinas Budaya dan Pariwisata Kabupaten Minahasa harus dapat memfasilitasi pembentukannya dan melakukan upaya penguatannya.

Selanjutnya Pokdarwis sebagai wadah dari masyarakat untuk melakukan aksesakses yang diinginkan, maka perlu adanya upaya-upaya penguatan Pokdarwis Desa Wisata Urongo. Penguatan lembaga Pokdarwistersebutdilakukanagar Pokdarwis mampu menyusun program kerja yang jelas dan mampu menjadi lembaga yang mandiri pengelolaan desa wisata. Jika penguatan lembaga Pokdarwis dapat dilakukan dengan baik maka diharapkan dapat mengantarkan Desa Wisata Urongo menuju pengembangan yang lebih baik. Lembaga Pokdarwis tersebut tidak saja hanya terbatas mampu menyusun program kerja, tetapi termasuk mengendalikan program ekonomi, lingkungan, sosial kebudayaan; melakukan perencanaan program pendidikan dan pelatihan; menyusun strategi marketing, peraturan yang berhubungan dengan wisata, dan lain sebagainya. Dalam hal ini Dinas Budaya dan Pariwisata Kabupaten Minahasa harus mampu berperan dalam penguatan lembaga Pokdarwis Desa Wisata Urongo.

Kemudian pada aspek penguatan kemitraan maka pemberdayaan masyarakat di Desa Wisata Urongo dilakukan oleh berbagai aktor yang terlibat. Konteks kemitraan dalam pemberdayaan masyarakat dalam pengembangan Desa Wisata Urongo adalah kemitraan yang terjalin antara aparat pemerintahan Kelurahan Urongo, Dinas Budaya dan Pariwisata Kabupaten Minahasa, perguruan tinggi-perguruan tinggi di 
wilayah Sulawesi Utara dan instansi-instansi pemerintah lain seperti Kementerian KKP, BP DAS Tondano, PLN, TNI dan Polri. Kemitraan ini dilakukan karena terdapat prinsip saling membutuhkan dan saling menguntungkan. Karena pada dasarnya masing-masing pihak memiliki kelebihan dan kelemahan yang mana masing-masing pihak tersebut akan saling melengkapi yang lain dan sebaliknya.

Dari data penelitian yang didapat menunjukkan bahwa peran serta dari masyarakat lokal sangat penting untuk pengembangan Desa Wisata Urongo. Masyarakat sudah seharusnya menjadi pelaksana kegiatan pengembangan desanya. Peran dari masyarakat dibutuhkan karena mereka yang mengetahui kondisi dan menjadi tuan rumah di desanya. Dengan adanya partisipasi masyarakat yang aktif akan mampu meningkatkan pendapatan, mengurangi angka pengangguran dan kemiskinan, menciptakan masyarakat yang kreatif, dan menjadi sarana untuk melestarikan kearifan lokal.

Terkait dengan bentuk-bentuk pengembangan Desa Wisata Urongo maka ada pihak-pihak yang terlibat langsung pariwisata maupun tidak langsung. Bentuk pengembangan pertama yaitu pengembangan SDM. Yang merupakan merupakan SDM yang dituntut memiliki kemampuan kewirausahaan. Kelompok Sadar Wisata atau Pokdarwis misalnya harus memiliki keterampilan Teknis manajemen untuk dapat mengoptimalkan faktorfaktor baik sumber daya alam, tenaga kerja, material dan sumber lainnya sehingga dapat meningkatkan nilai jual melalui kreativitas dan inovasi. Pengelola wisata juga dituntut memiliki kemampuan baik manajemen maupun keterampilan Teknis. Kemampuan manajemen bagi pengelola wisata penting untuk mampu memanfaatkan segala peluang usaha. Keterampilan Teknis seperti pengelolaan, administrasi keuangan dan pemasaran. Sedangkan para pelaku langsung di lapangan juga tidak kalah pentingnya.
Mereka dituntut memiliki keterampilan khusus dan menguasai bidang pekerjaan secara teknis atau dengan kata lain menjadi sumber daya manusia atau tenaga terampil atau minimal setengah terampil. Oleh karenanya dalam pengembangan SDM disesuaikan dengan tuntutan keterampilan yang dimiliki.

Pengembangan sumber daya manusia di Desa Wisata Urongo dilakukan melalui pelatihan-pelatihan, diskusi, maupun kegiatan lain yang berhubungan dengan kepariwisataan. Pelatihan-pelatihan tersebut macam dan jenisnya disesuaikan dengan kebutuhan dalam pengembangan desa wisata. Pelatihan bagi anggota pokdarwis dan pengelola wisata yaitu terkait manajemen pengelolaan desa wisata, pembukuan tentang wisata,struktur organisasi. Sedangkan pelatihan-pelatihan berupa kemampuan atau keterampilan Teknis seperti keterampilan pemandu wisata, keterampilan bahasa asing bagi pemandu wisata dan penerjemah. Kemudian pelatihan bahasa asing praktis juga perlu diberikan kepada pelaku pendukung pariwisata yakni penjaga, pedagang, tukang parkir. Sedangkan pelatihan lain yang juga perlu diprogramkan yaitu pelatihan kuliner untuk pedagang/ penjual maupun anggota PKK. Pelatihan lain yang dibutuhkan yaitu pengelolaan homestay bagi pemilik homestay. Jenis pelatihan lain dalam pengembangan Sumber Daya Manusia yang sesuai dengan pengembangan Desa Wisata Urongo yaitu pelatihan selama pelatihan instruktur outbond.

Selanjutnya mengenai kemitraan. menurut Yusuf Wibisono (2007: 103) dalam melakukan kemitraan terhadap tiga prinsip penting, yaitu kesetaraan atau keseimbangan, transparansi, dan saling menguntungkan. Kemitraan yang telah dilaksanakan yaitu dengan perguruan tinggi-perguruan tinggi yang ada di Sulawesi Utara. Kemitraan dengan Universitas Negeri Manado yaitu sebagai lokasi Kuliah Kerja Nyata atau KKN Mahasiswa. Kemitraan 
dengan Universitas Sam Ratulangi dalam hal kegiatan penelitian-penelitian. Kemitraan dengan STIPAR Manado dan Politeknik Manado jurusan pariwisata. Dalam rangka pengembangan Desa Wisata Urongo sesuai dengan potensi yang dimilikinya masih ada pihak-pihak lain yang dapat dijadikan mitra dalam pengembangan Desa Wisata Urongo. Pihak-pihak lain misalnya PLN untuk program pengembangan teknologi, BP DAS Tondano untuk pengembangan potensi budi daya perikanan. Dengan TNI dan Polri setempat yakni Polres Minahasa dan Kodim Minahasa misalnya dalam kegiatan TMMD dan penghijauan. Termasuk kemitraan dengan IPDN Kampus Sulawesi Utara juga perlu direalisasikan. Sebagai perguruan tinggi kepamongprajaan yang mencetak kader pemerintahan dan juga memiliki program Tri Darma Perguruan Tinggi dapat menjalin kemitraan yaitu dalam peningkatan kualitas administrasi pemerintahan kelurahan, sebagai lokasi kegiatan pengabdian masyarakat. Bahkan dapat menjadi laboratorium lapangan pengembangan ilmu pemerintahan.

Terkait dengan kegiatan pemerintahan maka kegiatan pemerintahan di desa yang dapat dilakukan antara lain seperti pelaksanaan musyawarah perencanaan pembangunan/musrenbang tingkat kelurahan, sosialisasi rapat-rapat dinas, keikutsertaan dalam pameran pembangunan dan lain-lain. Kegiatan Musrenbang merupakan kegiatan yang sangat penting dan strategis bagi pemerintah kelurahan dan masyarakat untuk dapat merencanakan pembangunan yang diarahkan bagi dukungan pengembangan Desa Wisata Urongo. Kegiatan-kegiatan sosialisasi dapat direncanakan materi-materi sosialisasi yang dapat mendukung program pengembangan desa wisata melalui kemitraan yang dilakukan.

Selanjutnya tentang promosi. Menurut Herlambang dan Bambang Heru (2009 : 106-107) pemasaran adalah salah satu kegiatan dalam perekonomian yang membantu dalam menciptakan sebuah nilai ekonomi. Sementara itu menurut Basu Swastha dan Sukaoso pemasaran adalah sistem secara keseluruhan dari kegiatan usaha yang ditujukan untuk perencanaan, menentukan harga, mempromosikan dan mendistribusikan barang dan jasa yang dapat memberikan kepada pembeli yang ada maupun pembeli yang potensial Dengan pentingnya Promosi maka pengembangan yang dilakukan Desa Wisata Urongo adalah dengan mengikuti berbagai pameran, peliputan oleh media televisi, iklan, promosi penjualan, pemasaran dari mulut ke mulut,dan publikasi. Pameran yang rutin diselenggarakan adalah pameran pembangunan Kabupaten Minahasa pada peringatan proklamasi kemerdekaan dan hari jadi Kabupaten Minahasa. Peliputan oleh media televisi yang difasilitasi oleh Dinas Budaya dan Pariwisata Kabupaten Minahasa. Sedangkan promosi dapat dilakukan oleh berbagai pihak dan yang utama adalah warga masyarakat dengan memanfaatkan aktivitas di media sosial.

Bentuk pengembangan Desa Wisata Urongo melalui kegiatan lomba yang pernah dilakukan yaitu lomba foto pemandangan danau Tondano yang cukup sukses meningkatkan popularitas Urongo sebagai desa wisata. Pada masa depan perlu digagas berbagai lomba yang mampu meningkatkan kunjungan wisata di desa wisata urongo. Lomba-lomba sederhana yang dapat dilakukan misalnya lomba olahraga, lomba memancing dan lomba melukis. Jika sanggar seni sudah terlaksana maka dapat diprogramkan pada hari libur tertentu Desa Wisata Urongo dapat mengadakan festival seperti pertunjukan seni tradisional. Juga menarik untuk membuat film atau syooting film tentang terjadinya Danau Tondano.

Dalam membina organisasi masyarakat yang memiliki potensi dalam pengembangan Desa Wisata Urongo di antaranya adalah PKK, Dasa Wisma, Generasi Muda Pencinta Alam dan komunitas pelaku seni. Organisasi 
PKK dan Dasa Wisma memiliki potensi yang besar jika diberikan pelatihanpelatihan yang bermanfaat yang terkait dengan pengembangan Desa Wisata Urongo misalnya pelatihan kuliner, pengembangan tanaman-tanaman pangan,tanaman hias dan membuat kerajinan/hiasan/souvenir. Juga pelatihan seperti pengembangan tanaman hias Dengan potensi seperti kemampuan IT dan kemampuan berorganisasi serta kelebihannya sebagai anak muda yang penuh dengan ide dan aktif berkegiatan dapat menjadi Sumber Daya Manusia yang handal.

Bentuk pengembangan kerja sama dengan universitas yaitu melakukan kegiatan pengembangan akademik dan kegiatan pengabdian. Dalam bidang pengembangan akademik misalnya kegiatan pengkajian-pengkajian yang dilakukan dalam pengembangan desa wisata akan dapat diperoleh berbagai terobosan yang mungkin dapat diterapkan oleh Pemerintah Kabupaten Minahasa maupun Pemerintah Kelurahan Urongo. Kegiatan pengembangan lainnya misalnya mahasiswanya dilibatkan dalam kegiatan bedah potensi wisata yang ada di Desa Wisata Urongo maupun desa wisata lainnya. Hal ini berguna untuk membuka peluang berkembang dan memberikan masukan bagi pengembangan desa wisata.

Peran dari masyarakat ini perlu diseimbangkan dengan peran pemerintah dan peran swasta. Destinasi wisata Tree House yang dikelola oleh kelompok orang yang tergabung dalam pengelola destinasi wisata memiliki kedudukan yang penting. Sebagai perintis destinasi wisata dan juga telah memiliki berbagai sarana dan prasarana pariwisata yang dikembangkan sehingga berperan penting dalam memperkenalkan Urongo sebagai salah satu destinasi wisata yang diperhitungkan. Tetapi hal ini masih menjadi suatu kendala tersendiri karena peraturan dan ketentuan yang kurang memungkinkan seperti pemberian bantuanbantuan.
Selain itu pemerintah berperan sebagai fasilitator yang menyediakan pelatihan kepada masyarakat, memberi bantuan PNPM Mandiri Pariwisata, selain itu memfasilitasi pihak-pihak yang ingin memberikan kontribusinya dalam pengembangan Desa Wisata Urongo. Tetapi, peran masyarakat dalam pengembangan Desa Wisata Urongo masih relatif rendah. Hal ini disebabkan karena keterbatasan kemampuan masyarakat dalam mengelola potensi-potensi desanya. Juga bentuk PNPM yang diberikan belum dalam bentuk PNPM MandiriPariwisatasehinggapemanfaatannya masih belum secara utuh diperuntukan untuk pengembangan desa wisata. Hal ini juga berpengaruh dalam hal keikutsertaan masyarakat dalam pengembangan desa wisata belum terlalu besar.

Selanjutnya adalah analisis terhadap faktor pendukung dan faktor penghambat. Faktor pendukung dalam penelitian ini yaitu, pertama, potensi wisata yang ada di Desa Wisata urongo dapat dikembangkan menjadi potensi pariwisata yang dapat memajukan perekonomian desa. Kedua, semangat dan respons positif dari masyarakat. Keterlibatan masyarakat sebagai pelaku wisata sudah ditunjukkan oleh masyarakat dalam kegiatan penjagaan loket, pemandu wisata, penjual makanan dan lain sebagainya. Ketiga, Pemerintah Kelurahan Urongo telah pernah memperoleh bantuan PNPM sebanyak 4 (empat) kali yaitu pada 2012, 2013, 2015 dan 2016 serta Bantuan Program Kotaku pada 2017. Dana tersebut digunakan untuk pembangunan sarana dan prasarana dalam rangka peningkatan kualitas kesehatan masyarakat dan kualitas lingkungan hidup. Sedangkan sebagai faktor penghambat yang ditemukan dalam penelitian ini adalah kualitas SDM masyarakat Desa Wisata Urongo. Tingkat pemahaman masyarakat dalam hal kepariwisataan dapat dikatakan masih rendah. Pemerintah daerah telah melakukan upaya untuk peningkatan kualitas SDM di Desa Wisata Urongo dengan 
melakukan kegiatan pelatihan kuliner, pengelolaan destinasi wisata dan pelatihan pengelola homestay. Pemerintah terus melakukan kegiatan pelatihan-pelatihan agar masyarakat atau pelaku wisata dapat bekerja secara profesional dan berkompeten dalam melayani wisatawan dan menciptakan kesenangan serta kenyamanan kepada para wisatawan.

Faktor penghambat lainnya berkaitan dengan dasar hukum. Membangun konsep sebuah desa wisata diperlukan adanya peraturan atau dasar hukum untuk memutuskan konsep dan langkah desa wisata selanjutnya. Selama ini pemerintah daerah Kabupaten Minahasa belum memiliki dasar hukum yang mengatur tentang pengelolaan desa wisata. Namun demikian dalam hal ini proses dan tahapan dalam mewujudkan adanya dasar hukum sudah diupayakan sesuai dengan birokrasi. Sesuai peraturan yang berlaku maka Pokdarwis dan pengelola desa wisata ditetapkan menggunakan Surat Keputusan (SK) dari Dinas Pariwisata Kabupaten Minahasa atas usul dari pemerintah kelurahan Urongo. Proses ini merupakan lanjutan dari tahapan sebelumnya yakni telah adanya rekomendasi dari pihak kelurahan untuk melegalkan kegiatan kepariwisataan yang ada di Desa Wisata Urongo termasuk pembentukan Pokdarwis dan pengelola desa wisata. Kemudian Dinas Budaya dan Pariwisata Kabupaten Minahasa menyetujuinya dengan mengeluarkan Surat Keputusan.

Dasar hukum yang kuat dalam pengembangan desa wisata adalah Peraturan Daerah. Peraturan Daerah tersebut nantinya akan mengatur semua tentang ketentuan pengelolaan desa wisata mulai dari penentuan paket wisata, penarikan retribusi, tarif parkir, pengelolaan kuliner, akses jalan menuju lokasi wisata, dan pembuatan fasilitas penunjang kegiatan kepariwisataan. Permasalahan tentang retribusi merupakan masalah yang sering dihadapi karena tidak adanya dasar hukum yang jelas. Dengan adanya dasar hukum yang jelas akan menciptakan ketertiban, keteraturan, dan keserasian dari para penyelenggaraan kepariwisataan yaitu pemerintah, badanbadan usaha, dan masyarakat. Selain itu, menjadi pedoman yang jelas bagi para penyelenggaraan kepariwisataan dan menciptakan keadilan bagi mereka. Adanya kejelasan mengenai hasil-hasil yang diperoleh masyarakat lokal dan dapat memberi manfaat bagi kehidupannya.

Faktor penghambat lain berdasarkan data penelitian yang didapat maka dalam hal pelestarian budaya Minahasa dan ciri khas kehidupan manusia danau relatif kurang. Tidak adanya sanggar seni yang dilengkapi sarana dan prasarana pendukung sebagai sarana utama pelestarian budaya maka sulit bagi wisatawan untuk dapat melihat secara langsung budaya Minahasa. Demikian pula ciri khas kehidupan manusia danau yang mengandalkan mata pencaharian di danau yang seharusnya dapat merupakan atraksi yang juga dapat dilihat dan diikuti wisatawan sulit ditemui.

Sementara itu, mengenai kegiatan pemerintahan yang kurang optimal maka berdasarkan data penelitian yang didapat saat ini kantor kelurahan sebagai sarana dalam menjalankan kegiatan pemerintahan tidak berfungsi sudah beberapa tahun lamanya. Dengan kondisi ini sangat memengaruhi berjalannya penyelenggaraan pemerintahan. Dalam pengembangan Desa Wisata Urongo maka peran pemerintahan sangat penting. Peran tersebut misalnya dalam kegiatan perencanaan program, pelaksanaan kegiatan, administrasi dan pembinaan. Program pengembangan Desa Wisata Urongo tentunya harus sinergis dengan program pemerintahan. Kemudian dalam kegiatan yang dilakukan oleh masyarakat maka pemerintah berperan sebagai dinamisator atau penggeraknya. Dalam hal administrasi maka dengan penyelenggaraan administrasi yang tertib juga akan berpengaruh dalam ketersediaan 
data-data yang dibutuhkan dalam pengembangan desa wisata. Kemudian kegiatan pembinaan merupakan sarana untuk dapat dilakukannya kegiatan-kegiatan pembinaan. Sarana tempatuntuk melakukan kegiatan pembinaan ini pada umumnya adalah Kantor Kelurahan atau Kantor Desa Dengan demikian maka ketidakadaan Kantor Kelurahan memengaruhi kegiatankegiatan pemerintahan dalam mendukung pengembangan Desa Wisata Urongo.

ADapun faktor kurangnya pencatatan kepariwisataan maka dalam pengembangan desa wisata maka diperlukan data-data yang dapat digunakan sebagai dasar perencanaan, pengawasan dan evaluasi. Data-data tersebut dihasilkan melalui pencatatan-pencatatan yang kemudian diolah atau disajikan dan didokumentasikan.

Berdasarkan data penelitian yang didapat, peneliti melihat bahwa masih sangat kurangnya data-data terutama terkait pencatatan kunjungan wisatawan. Baik pencatatan di pemerintahan kelurahan pengelola desa wisata maupun destinasi wisata yang ada. Manfaat dari pencatatan ini adalah untuk pengawasan. Selain itu, sebagai bahan evaluasi bagi pengelola wisata untuk selalu kreatif dan inovatif untuk mengelola potensi wisata sehingga dapat meningkatkan jumlah kunjungan wisatawan.

\section{SIMPULAN}

Berdasarkan hasil penelitian dan pembahasan yang telah disusun oleh peneliti, maka dapat ditarik simpulan bahwa

a. Kegiatan pemberdayaan masyarakat dalam pengembangan Desa Wisata Urongo terdapat dua aspek yang cukup optimal yaitu kemitraan dan Bantuan Pendampingan dan tiga aspek yang belum optimal yaitu bantuan modal, pembangunan sarana dan prasarana serta penguatan kelembagaan. b. Upaya-upaya pengembangan Desa Wisata Urongo yang dilaksanakan terdapat upaya yang cukup optimal yaitu dalam kemitraan, promosi, pembinaan ormas, dan kerja sama dengan universitas. Sedang upaya yang belum optimal yaitu pengembangan SDM, pembangunan sarana dan prasarana, kegiatan pemerintahan di desa, kurangnya even festival atau lomba dan belum terbentuknya Pokdarwis dan Pengelola Desa Wisata.

c. Faktor Pendukung yang ada yaitu adanya potensi wisata yang cukup baik respons positif masyarakat dan pernah mendapatkan bantuan PNPM. Sedangkan faktor penghambat yang ada yaitu kualitas Sumber Daya Manusia, masih terbatasnya fasilitas wisata dan penunjang lainnya, belum adanya dasar hukum yang mengatur desa wisata dan juga belum terbentuknya Pokdarwis dan Pengelola Desa Wisata Urongo, kurangnya pelestarian seni budaya tradisional, kurang optimalnya kegiatan pemerintahan dan masih lemahnya pencatatan kepariwisataan.

\section{SARAN}

a. Rekomendasi terkait kegiatan dalam Pemberdayaan Masyarakat yaitu perlunya diusulkan dan direalisasikan pemberian Bantuan modal berupa PNPM Mandiri Pariwisata, perlunya pembangunan sarana dan prasarana utama sebagai desa wisata, segera dilaksanakan pembentukan kelembagaan Pokdarwis Desa Wisata Urongo dan Pengelola Desa Wisata Urongo.

b. Rekomendasi terkait pengembangan Desa Wisata Urongo yaitu meningkatkan pengembangan SDM melalui peningkatan keikutsertaan dalam pelatihan-pelatihan yang diselenggarakan dengan prioritas bagi Pokdarwis dan pengelola Desa 
Wisata Urongo dan pelaku-pelaku wisata yang terlibat langsung, melaksanakan pembangunansaranadanprasaranaberupa gardu pandang dan taman-taman buatan serta membantu perbaikan sarana dan prasarana di destinasi wisata Tree House, mengoptimalkan kegiatan pemerintahan di desa wisata dan memperbanyak even festival atau lomba untuk meningkatkan kunjungan wisatawan.

c. Rekomendasi terkait faktor pendukung dan faktor penghambat meliputi meningkatkan kualitas Sumber Daya Manusia dalam hal pengelolaan desa wisata dan meningkatkan minat masyarakat dalam mempersiapkan Desa Wisata Urongo, menambah berbagai fasilitas wisata dan penunjang lainnya di antaranya fasilitas utama, mempercepat proses penyusunan dasar hukum yang mengatur desa wisata dan dasar hukum guna legalisasi pembentukan Pokdarwis dan Pengelola Desa Wisata Urongo, meningkatkan pelestarian seni budaya tradisional dengan membangun sanggar seni dilengkapi dengan peralatan dan perlengkapan dan bantuan pelatihan seni tradisional, mengoptimalkan kegiatan pemerintahan dan meningkatkan kesadaran pelaksanaan pencatatan kepariwisataan

\section{Rekomendasi Terkait Penelitian} Lanjutan. Sebagai wilayah yang cukup dekat dengan dislokasi IPDN Kampus Sulawesi Utara peneliti juga tertarik meneliti tentang Implementasi Administrasi Pemerintahan Desa/Kelurahan di Desa Urongo.

\footnotetext{
Rekomendasi Terkait Pengabdian Masyarakat IPDN Kampus Sulawesi Utara.

Peneliti merekomendasikan agar kegiatan pada kegiatan pengabdian masyarakat salah satu jenis kegiatan pengabdian masyarakat memilih Kelurahan Urongo sebagai sasaran kegiatan.berupa penyusunan profil desa dan kelurahan sehingga memiliki profil kelurahan yang baik.
}

\section{DAFTAR RUJUKAN}

Ambar Teguh Sulistiyani, 2004,Kemitraan dan Model-Model Pemberdayaan, Yogyakarta, Gaya Media

Arikunto, Suharsimi. 2006. Prosedur Penelitian, Suatu Pendekatan Praktik. Jakarta: Rineka Cipta.

Burhan Bungin,2003, Analisis Data Penelitian Kualitatif, Jakarta, PT Raja Grafindo Persada

Heny, Andi Nurdin, 2019. Pengembangan Masyarakat dan Pemberdayaan Ekonomi di Indonesia. Bandung: CV Cendekia Press

Herlambang S dkk, 2019. Pengantar Ilmu Bisnis. Bandung: CV Cendekia Press

Koentjoroningrat. 2009. Pengantar Ilmu Antropologi, Jakarta: Rineka Cipta.

Lexy J Moleong, 2007, Metodologi Penelitian Kualitatif, Bandung, Remaja Rosdakarya

Mardi Yatmo Hutomo, 2000, Pemberdayaan Masyarakat dalam Bidang Ekonomi, Tinjauan Teoretis dan Implementasi, Bandung, Remaja Rosdakarya

Suharto, Edi. 2010. Membangun Masyarakat Memberdayakan Rakyat. Bandung: PT Refika Aditama.

Patilima,Hamid,2010. Metode Penelitian Kualitatif, Bandung: Alfabeta.

Pusat Bahasa Depdiknas, Kamus Besar Bahasa Indonesia Edisi Ketiga, Jakarta, Balai Pustaka

Riduwan dkk. 2010, Skala Pengukuran Variabelvariabel Penelitian, Bandung: IKAPI.

Sugiyono. 2012. Metode Penelitian Pendidikan, Pendekatan Kuantitatif, Kualitatif, dan $R \& D$. Bandung: Alfabeta.

Suryana, 2006, Kewirausahaan Pedoman Praktis,: Kiat dan Proses Menuju Sukses, Salemba Empat

Suryana, 2010, Kewirausahaan, Yogyakarta, Penerit Andi

\section{Jurnal/Tesis}

Ani Siswandi Putra, 2013, Pola Kemitraan Pariwisata Dalam Manajemen Atraksi Desa Wisata Pampang Kota Samarinda, 
diakses pada 10 Oktober 2020 pukul 11.30 Wita

Darwis,Ilham Junaid, 2016. Kemitraan sebagai Strategi Pengembangan Pariwisata dan Industri Hospitaliti, diakses pada 10 Oktober 2020 pukul 10.24 Wita

Oktavia Suryaningsih, Joko Tri Nugroho, 2018, Peran Lembaga Desa dalam Pengembangan Desa Wisata Wanurejo dan dampaknya terhadap Perekonomian Masyarakat, diakses pada 26 September 2020 pukul 20.36 Wita

Rudi Lukman Hakim,Ausyani More, 2017, Kemitraan Pemerintah dengan ASITA dalam Promosi Kunjungan Wisata di Dinas Kebudayaan dan Kepariwisataan Provinsi Sulawesi Selatan, diakses pada 10 Oktober 2020 pukul 11.30 Wita

Nancy Onibala, 2018, Tesis: Pengembangan Ekowisata Berbasis Partisipasi Masyarakat pada Wisata Tree House Urongo Kabupaten Minahasa Provinsi Sulawesi Utara, diakses pada 2 September 2020 pukul 10.17 Wita

\section{Website}

https ://berita manado.com/Pemkab minahasa harus ada catatan jumlah kunjungan wisatawan, diakses pada 11 Oktober 2020 pukul 17.13 Wita

penelusuran perkembangan pariwisata sulawesi utara, diakses pada 11 Oktober 2020 pukul 17.12 Wita

penelusuran jumlah kunjungan wisatawan ke minahasa, diakses pada 11 Oktober 2020 pukul 17.12 Wita

penelusuran Perdes Nila No 5 Tahun 2014 tentang Pengembangan Desa Wisata, diakses pada 11 Oktober 2020 pukul 11.02 Wita

penelusuran arti pendampingan dalam pemberdayaan masyarakat, diakses pada 10 Oktober 2020 pukul 09.47 Wita

penelusuran pengertian kelembagaan masyarakat, diakses pada 11 Oktober 2020 pukul 11.21 Wita 